\title{
Situation of bovine tuberculosis in Ecuador
}

\section{Freddy Proaño-Pérez, ${ }^{1}$ Washington Benítez-Ortiz, ${ }^{1}$ Françoise Portaels, ${ }^{2}$ Leen Rigouts, ${ }^{2}$ and Annick Linden ${ }^{3}$}

Suggested citation: Proaño-Pérez F, Benítez-Ortiz W, Portaels F, Rigouts L, Linden A. Situation of bovine tuberculosis in Ecuador. Rev Panam Salud Publica. 2011;30(3):279-86.

\section{SYNOPSIS}

Bovine tuberculosis (BTB) is a chronic and contagious disease that affects domestic animals, wildlife, and humans. Caused by Mycobacterium bovis, BTB causes major economic losses and poses a serious constraint to international livestock trade. Moreover, in developing countries where $B T B$ controls are lacking, $M$. bovis is a public health concern. In most developing countries, the prevalence of BTB in livestock is unknown because the information is either not reported or not available. In Ecuador, there is no national BTB control program.

This article reviews the BTB situation in Ecuador by examining exhaustive data from tuberculin testing surveys and slaughterhouse surveillance studies conducted in 1972-2008 in a variety of the country's geographic areas. In Ecuador, several factors, including the dairy industry's expansion (preempted by the high demand for milk and its byproducts), intensified efforts to increase the cattle population, the presence of $\mathrm{M}$. bovis, and a lack of BTB controls, have caused a rise in BTB prevalence, and consequently, a growing push for the implementation of a national BTB control program.

Key words: Mycobacterium bovis; zoonoses; cattle diseases; tuberculosis, bovine; communicable diseases, emerging; Ecuador.

\footnotetext{
International Center for Zoonoses, Central University of Ecuador, Quito, Ecuador

2 Mycobacteriology Unit, Department of Microbiology, Institute of Tropical Medicine of Antwerp, Antwerp, Belgium.

3 Department of Infectious and Parasitic Diseases, Faculty of Veterinary Medicine, University of Liege, Liege, Belgium.
}

Bovine tuberculosis (BTB) is a chronic infectious disease caused by Mycobacterium bovis. This disease mainly affects cattle, but can also be found in other domestic and wild animals, and occasionally, in humans (1). The World Organization for Animal Health (OIE) considers BTB to be an important zoonotic disease with a socioeconomic and public health impact that affects the international trade of livestock and animal products (2).

The prevalence of BTB in developing countries remains largely unknown. According to a study conducted in 2006, Ecuador is among a group of Latin American countries assumed to have a relatively high prevalence of BTB, but a lack of reporting (3). Other countries in the group are Argentina, Bolivia, Brazil, Chile, Guatemala, Guyana, Haiti, and Peru. In 1998, it was estimated that for $24 \%$ of the Latin American bovine population, control measures for BTB were incomplete or inexistent (4). This absence of control represents a high risk for the rural inhabitants living in direct contact with animals (5). Of approximately 374 million cattle in Latin America and the Caribbean, 70\% are held in areas where $M$. bovis infection rates among cattle exceed $1 \%$ (3).

In humans, the proportion of tuberculosis induced by $M$. bovis is relatively low compared to $M$. $t u$ berculosis. In recent years, however, $M$. bovis tuberculosis in humans has become increasingly prevalent among human populations subjected to poverty, malnutrition, human immunodeficiency virus (HIV), and inadequate health care (6). Transmission through the consumption of unpasteurized milk and dairy products from infected cattle occurs mostly among the general public, whereas exposure through airborne infection remains highest among farmers, veterinarians, and slaughterhouse workers (6). According to a study published in 1998, M. bovis could be responsible for more than $2 \%$ of the total pulmonary tuberculosis (TB) cases and $9.4 \%$ of extrapulmonary forms among humans in Latin America, a considerable number. In addition, another study showed that in Argentina, 2\% of human TB cases have been recorded as being caused by $M$. bovis (3).

Given the appearance of new cases in recent years, BTB in humans has been designated a reemerging disease in developed countries. Reemergence is most likely the result of increased world population, augmented by the movement of people and animals, environmental changes, crossing of the interspecies barrier, and changes in livestock production management $(4,7,8)$.

The total economic losses due to BTB are underestimated because its impact on public health has not been thoroughly evaluated (9). Estimates of economic 
loss are limited to animal health issues and are based on weight loss, decreased milk production, lower reproduction rates, mortality, and condemnation of carcasses (10). In Argentina, the National Health and Food Safety Service (Servicio Nacional de Sanidad y Calidad Agroalimentaria) estimates that in 1995 annual losses due to BTB were approximately US\$ 63 million (4).

This article aims to provide information on the current situation of BTB in Ecuador based on available data from studies of tuberculin skin-testing at farms, veterinary inspections at slaughterhouses, and laboratory-based diagnoses. The data presented in this article were obtained from the college libraries serving schools of veterinary medicine throughout the country. Most of the surveys were a component of veterinary students' theses. In Ecuador, there is only one research group working on BTB, which explains the limited number of published studies.

\section{BTB PREVALENCE}

BTB cases in Ecuador are not documented nor quantified clearly for several reasons: lack of proper recording of positive cases, limited use of diagnostic tests, and insufficient veterinary inspection in most slaughterhouses, but mainly because BTB is not a noti- fiable disease. Furthermore, it is not unlikely that in Ecuador, as may be the case in other countries, BTB is not reported due to a lack of trust between farmers and health officials (5). Currently, control measures related to relocation and transportation of animals focus solely on Foot and Mouth Disease. Furthermore, results of veterinary inspection are not recorded properly in slaughterhouses, jeopardizing the "traceability" of positive BTB cases observed during these inspections.

BTB prevalence can be influenced by several factors at the individual, herd, provincial, or country level (11). For instance, livestock husbandry varies by herd size, farm size, and type of cattle industry, i.e., for dairy or meat production. Factors such as these can affect BTB disease occurrence by increasing or decreasing close contact among animals. In Ecuador, the cattle population is not equally distributed, for example, the provinces of Azuay and Pichincha have dense livestock populations predominantly focused on dairy production, while Santo Domingo and Manabí provinces have important meat industries (12). This variation of distribution also impacts BTB occurrence.

The scarce information that is available in Ecuador is mostly based on tuberculin skin-testing performed by students at the schools of veterinary medicine within the various universities of Ecuador (Figure 1).

FIGURE 1. Studies conducted using tuberculin skin tests and veterinary inspections to determine prevalence of bovine tuberculosis (BTB), Ecuador, 1972-2008

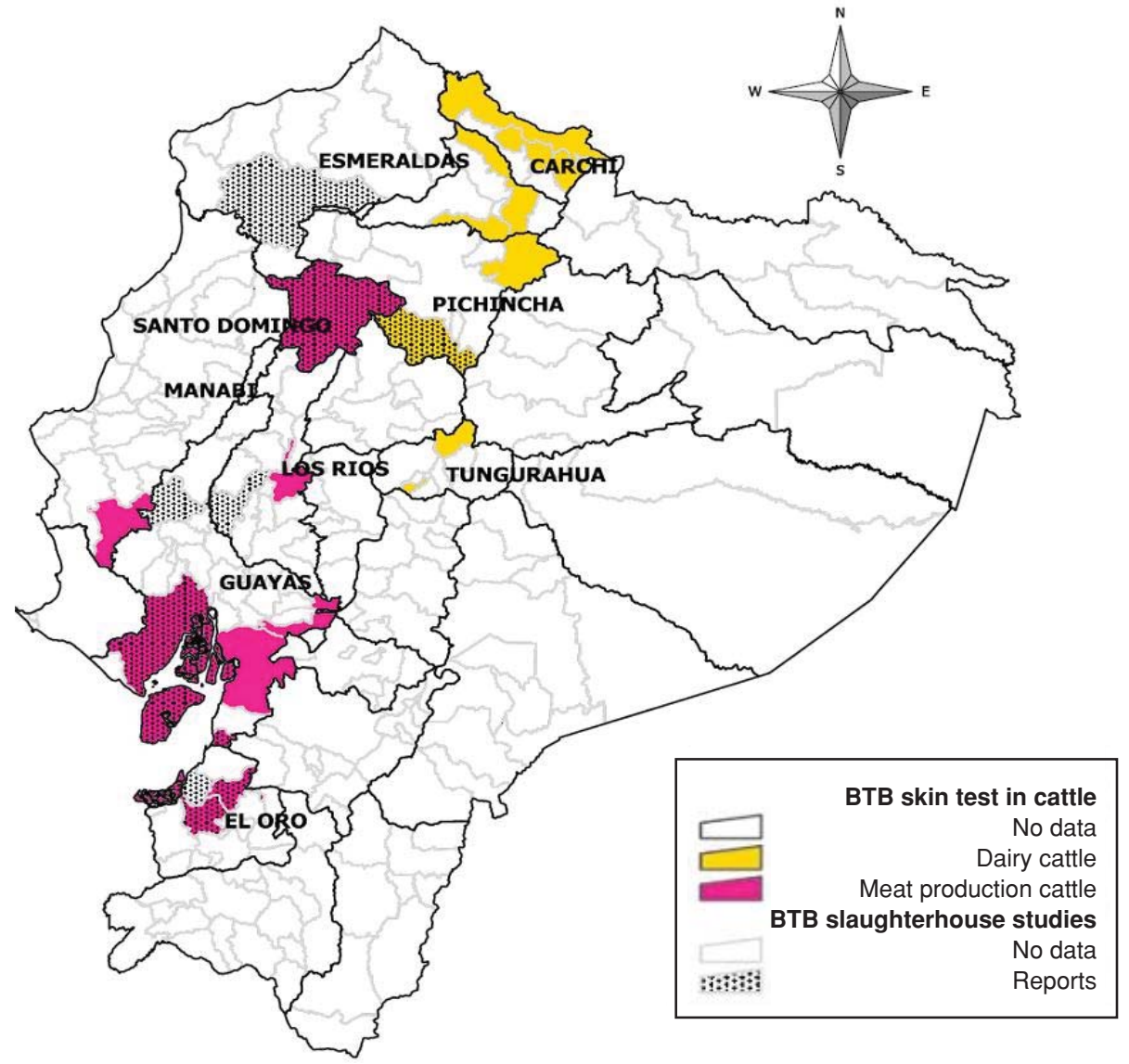




\section{Tuberculin skin test surveys}

The sensitivity of skin testing can be affected by the potency and dose of tuberculin administered, the post-infection interval, desensitization, deliberate interference, postpartum immunosuppression, variation in the interpretation by the observer, and contact with environmental non-tuberculous mycobacteria (NTM) (13). Surveys performed in Ecuador using the single and comparative intradermal tuberculin test (SITT and CITT, respectively) have demonstrated a variable prevalence of BTB. Briefly, the tuberculin skin test is based on the use of bovine purified protein derivative AN5 strain (PPD-B) $20000 \mathrm{IU} / \mathrm{mL}$ and avian purified protein derivative D4 ER strain (PPD-A) $25000 \mathrm{IU} / \mathrm{mL}$; it can be applied in the caudal fold of the tail (SITT) or in the middle third of the neck (CITT); and the thicknesses of the skin is measured with calipers 72 hours before and after the injection of $0.1 \mathrm{~mL}$ PPD-A and PPD-B antigens. The interpretation is based on the reaction observed $(14,15)$. In most of the studies performed in Ecuador, the PPD antigens used were not reported.

Table 1 presents an overview of the tuberculintesting surveys conducted in dairy cattle in Ecuador (16-21). In 1977, the first survey detected a low (0.3\%) prevalence among dairy cattle in the Tungurahua province located in the middle of the country (16). A second study conducted in 2003 in the same area showed an increased prevalence of $1.2 \%$ (17). In both studies, SITT was applied in all animals, and CITT was used to confirm all positive and suspected cases detected. Data on the herd size and origin of the PPD reagents were not presented in these studies.

In contrast, in the province of Imbabura, a survey conducted in 2001 showed a high prevalence of BTB $(7.3 \%)$ (18). However, 2 years later, it showed a lower prevalence (2.4\%) (19). In the province of Carchi, located north of the Imbabura province at the border with Colombia, the prevalence observed in $2001(2.1 \%)$ was comparable to that of $2002(1.7 \%)(18,20)$. In gen- eral, the prevalences found in Imbabura and Carchi were higher than in Tungurahua. This was probably due to the smaller cattle population and lower animal density of Tungurahua. Plus, Tungurahua is an area more focused on agriculture than animal production (12).

The majority of the surveys, however, were performed in the province of Pichincha, specifically in the cantons of Mejía and Cayambe, the two most important dairy areas, located near the capital city, Quito. In 2001, a prevalence of $2.8 \%$ was observed in the Cayambe canton (18). This finding was in sharp contrast to a prevalence of $0.5 \%$ reported a year later (21). Worth noting is that the first study sampled only two farms; therefore, the BTB prevalence data is questionable.

Studies performed in the Mejía canton showed a high occurrence of the disease in dairy cattle. In 2002, a study (22) observed $4.9 \%$ skin reactors, which was confirmed by the prevalence of $3.9 \%$ found by another survey applied in the same area, but to different herds (14). The two studies used similar diagnostic methods, but sampling procedures differed. In the latter study, 22 cattle were randomly selected per herd from farms that were small (1-25 cattle), medium (25-70 cattle), and large ( $>70$ cattle). The diagnostic test used was CZV Bovine Tuberculin PPD ${ }^{\circledR}$ (CZ Veterinaria S.A., Porriño, Spain). The difference found related to herd size was highly significant: $7.9 \%$ in large herds; $3.4 \%$ in medium; and surprisingly, only $0.3 \%$ in small herds (14). Recent information from CITT analysis, using Bovituber ${ }^{\circledR}$ PPD (Synbiotics Corporation, a subsidiary of Pfizer Incorporated, Lyon, France) in 20 dairy herds in the Mejía canton showed an annual incidence of $1.7 \%$, with a true prevalence at $7.1 \%$. Herd size was identified as a main risk, as were age $(P=0.03)$, contact with other animal species $(P<0.01)$, and introducing new animals into the herd $(P=0.04)(15)$.

The expansion of the dairy industry in Ecuador-resulting from a growing population and its high demand for milk and by-products-meant closer

TABLE 1. Apparent prevalence of bovine tuberculosis in dairy cattle according to available studies, Ecuador, 1977-2008

\begin{tabular}{|c|c|c|c|c|c|c|c|c|}
\hline \multirow[b]{2}{*}{ Reference } & \multirow[b]{2}{*}{ Year } & \multicolumn{2}{|c|}{ Location } & \multirow{2}{*}{$\begin{array}{l}\text { Test } \\
\text { used }\end{array}$} & \multirow{2}{*}{$\begin{array}{l}\text { Herd } \\
\text { size }^{a}\end{array}$} & \multirow{2}{*}{$\begin{array}{l}\text { No. of } \\
\text { Herds }\end{array}$} & \multirow{2}{*}{$\begin{array}{l}\text { Positive cattle/ } \\
\text { No. of animals }\end{array}$} & \multirow[b]{2}{*}{$(\%)$} \\
\hline & & Province & Canton & & & & & \\
\hline Acosta \& Parreño (16) & 1977 & Tungurahua & Píllaro & $\mathrm{SITT}^{\mathrm{b}} \& \mathrm{CITT}^{\mathrm{c}}$ & $N A^{d}$ & 20 & $7 / 2132$ & 0.33 \\
\hline \multirow[t]{3}{*}{ Andino-Ashqui (18) } & 2001 & Pichincha & Cayambe & SITT \& CITT & Large & 2 & $5 / 178$ & 2.81 \\
\hline & & Imbabura & Otavalo & & Large & 1 & $24 / 329$ & 7.29 \\
\hline & & Carchi & Espejo & & Large & 2 & $11 / 516$ & 2.13 \\
\hline Salazar \& Cevallos (21) & 2002 & Pichincha & Cayambe & SITT \& CITT & NA & 26 & $14 / 3006$ & 0.47 \\
\hline Cano \& Chulde (22) & 2002 & Pichincha & Mejía & SITT \& CITT & Large & 13 & $152 / 3089$ & 4.92 \\
\hline Burbano \& Léon (20) & 2002 & Carchi & $\begin{array}{l}\text { Espejo, Tulcán } \\
\text { Montufar, Huaca }\end{array}$ & SITT \& CITT & NA & NA & $52 / 3011$ & 1.73 \\
\hline Bedón \& Verdesoto (19) & 2003 & Imbabura & Ibarra, Otavalo & SITT \& CITT & Large & 13 & $73 / 3005$ & 2.43 \\
\hline Alemán, et al. (17) & 2003 & Tungurahua & Píllaro, Mocha & SITT \& CITT & $\mathrm{NA}$ & 24 & $49 / 4012$ & 1.22 \\
\hline Proaño-Pérez, et al. (14) & 2006 & Pichincha & Mejía & SITT \& CITT & Large & 15 & $26 / 327$ & 7.95 \\
\hline Proaño-Pérez, et al. (15) & 2007 & Pichincha & Mejía & CITT & Large & 13 & $142 / 1644$ & 8.63 \\
\hline Proaño-Pérez, et al. (15) & 2008 & Pichincha & Mejía & CITT & Large & 13 & $122 / 1446$ & 8.43 \\
\hline
\end{tabular}


contact among animals. This increased the risk of transmitting $M$. bovis bacilli (23).

Breed-related differences have been reported (1), with BTB infecting a higher proportion of dairy breeds (Bos taurus), than indigenous zebu cattle (Bos indicus) and crossbred beef cattle. Additionally, the use of the European breeds (e.g., the Holstein Friesian) to improve milk production through artificial insemination, resulted in higher BTB susceptibility (24), indirectly increasing the probability of BTB infections. Beef cattle husbandry systems differ from dairy management and have a decreased risk of infection due to less contact between animals (25). Meat production farms in Ecuador often have expansive pastures and most are located in tropical areas.

Table 2 summarizes all available studies conducted on beef cattle in Ecuador (26-36). All surveys showed a low number of skin reactors, except for two studies in the province of Guayas that showed prevalences of $3.4 \%$ and $5.6 \%$. This high percentage can be attributed to the fact that in both studies only SITT was applied and positive reactors were not confirmed by CITT. Some of the reactions, therefore, could have been caused by contact with environmental NTM, especially in young cattle $(13,37)$.

\section{Veterinary inspection}

In geographic areas with high BTB, prevalence rates can be estimated by the proportion of macroscopic tuberculous lesions detected during postmortem examination (followed by the rejection of carcasses and viscera from these animals), if a reliable system exists (9). Indeed, programs based on slaughterhouse surveillance are only effective when they use a reliable traceability system for tracing-back to herd of origin. The distribution and development of lesions depend on the route of transmission (38), and location can vary, although most often they are found in tho- racic lymph nodes due to infection via the respiratory route (39). Therefore, exhaustive veterinary control needs to be established to identify affected animals, i.e., palpation and inspection of lungs, liver, spleen, kidney, mammary gland, and associated lymph nodes (39). Vigilance is recommended, however, since not all infected cattle exhibit gross lesions. On the other hand, detailed meat inspection allows the identification of lesions in apparently healthy animals, which increases the number of detected animals and avoids the consumption of BTB-infected cattle (40).

Although veterinary inspection at slaughterhouses potentially constitutes a good method for identifying the presence of $\mathrm{TB}$, it is not routinely implemented in Ecuador and only a few studies on the topic have been published. Those 14 studies are shown in Table 3 (40-52). The studies that took place in 1972-2003 were conducted in the provinces located in the tropical areas where meat production is the priority; later studies were performed mainly on dairy cattle in the highlands. The first study, conducted in 1972, entailed veterinary inspection at the slaughterhouse of Guayaquil to identify pigs with BTB (41). A low prevalence of $0.2 \%$ was found. More recently, a high proportion of affected dairy cattle were observed in $2007(2.3 \%)$ and $2008(2.2 \%)$ in the highlands of Ecuador, specifically the Mejía canton of the Pichincha province (40). The study applied various laboratorybased diagnostic methods, in addition to the macroscopic investigation. The presence of $M$. bovis was confirmed (40).

In Ecuador's dairy areas, $90 \%$ of the cattle in the highlands are Holstein Friesian, whereas in the tropical areas, the main breeds used for milk production are Jersey, Brown Swiss, and crossbreeds. The differences in BTB prevalence among cattle breeds and geographic areas present in Ecuador, were also found in the slaughterhouses of Argentina (9), Brazil $(53,54)$, and Mexico $(55,56)$.

TABLE 2. Apparent prevalence of bovine tuberculosis in meat production cattle according to available studies, Ecuador, 1977-2004

\begin{tabular}{|c|c|c|c|c|c|c|c|c|}
\hline \multirow[b]{2}{*}{ Reference } & \multirow[b]{2}{*}{ Year } & \multicolumn{2}{|c|}{ Location } & \multirow{2}{*}{$\begin{array}{l}\text { Test } \\
\text { used }\end{array}$} & \multirow{2}{*}{$\begin{array}{l}\text { Herd } \\
\text { size }^{a}\end{array}$} & \multirow{2}{*}{$\begin{array}{l}\text { No. of } \\
\text { Herds }\end{array}$} & \multirow{2}{*}{$\begin{array}{l}\text { Positive cattle/ } \\
\text { No. of animals }\end{array}$} & \multirow[b]{2}{*}{$(\%)$} \\
\hline & & Province & Canton & & & & & \\
\hline Cañizares (26) & 1977 & Guayas & Guayaquil & SITT'b & $N A^{c}$ & NA & $33 / 975$ & 3.38 \\
\hline Maretti (27) & 1981 & Galápagos & San Cristóbal & SITT & NA & NA & $0 / 1000$ & 0.00 \\
\hline Lojan (28) & 1982 & El Oro & Santa Rosa & SITT & NA & NA & $4 / 1465$ & 0.27 \\
\hline Aguirre (29) & 1984 & El Oro & Pasaje & SITT & NA & NA & $0 / 500$ & 0.00 \\
\hline Torres, et al. (30) & 1996 & Santo Domingo & Santo Domingo & SITT & Large & 1 & $21 / 4888$ & 0.43 \\
\hline Gutierrez (31) & 1997 & Guayas & El Triunfo & SITT & NA & NA & $0 / 300$ & 0.00 \\
\hline Muñoz (32) & 1998 & Los Ríos & Ventanas & SITT & NA & NA & $0 / 320$ & 0.00 \\
\hline Villamar (33) & 2000 & Manabí & Paján & SITT & NA & NA & $0 / 300$ & 0.00 \\
\hline Moncada (34) & 2003 & Guayas & Naranjal & SITT & NA & NA & $14 / 250$ & 5.60 \\
\hline Avellan (35) & 2003 & Guayas & Bucay & SITT & NA & NA & $2 / 200$ & 1.00 \\
\hline Arevalo \& Zamora (36) & 2004 & Santo Domingo & Santo Domingo & SITT \& CITT ${ }^{d}$ & Large & 37 & $20 / 4029$ & 0.50 \\
\hline
\end{tabular}


TABLE 3. Veterinary inspection performed on dairy and meat production animals to identify bovine tuberculosis in slaughtered animals, Ecuador, 1972-2008

\begin{tabular}{|c|c|c|c|c|c|c|}
\hline \multirow[b]{2}{*}{ Reference } & \multirow[b]{2}{*}{ Year } & \multicolumn{2}{|c|}{ Location } & \multirow{2}{*}{$\begin{array}{c}\text { Species } \\
\text { slaughtered }\end{array}$} & \multirow{2}{*}{$\begin{array}{l}\text { Positive cattle/ } \\
\text { No. of animals }\end{array}$} & \multirow[b]{2}{*}{$\%$} \\
\hline & & Province & Canton & & & \\
\hline Villacis (41) & 1972 & Guayas & Guayaquil & Porcine & $19 / 10739$ & 0.18 \\
\hline Mata (42) & 1973 & Guayas & Guayaquil & Bovine & $16 / 3425$ & 0.47 \\
\hline Cruz (43) & 1985 & El Oro & Machala & Porcine & $0 / 1500$ & 0.00 \\
\hline $\mathrm{Haz}(44)$ & 1987 & Los Ríos & Vinces & Porcine & $1 / 6420$ & 0.02 \\
\hline Cueto \& Suárez (45) & 1993 & Guayas & Guayaquil & Bovine & $28 / 23029$ & 0.12 \\
\hline Andrade (46) & 2000 & Guayas & Guayaquil & Caprine & $2 / 550$ & 0.36 \\
\hline Coloma (47) & 2000 & Santo Domingo & Santo Domingo & Bovine & $6 / 2778$ & 0.21 \\
\hline Villón (48) & 2002 & Guayas & Guayaquil & Bovine & $80 / 4200$ & 1.90 \\
\hline Torres (49) & 2002 & El Oro & Pasaje & Bovine & 0/1 395 & 0.00 \\
\hline Jaramillo (50) & 2002 & El Oro & Santa Rosa & Bovine & $0 / 1047$ & 0.00 \\
\hline Jauregui (51) & 2003 & Guayas & Colimes & Bovine & $0 / 283$ & 0.00 \\
\hline Mera (52) & 2003 & Esmeraldas & Quinindé & Bovine & $0 / 400$ & 0.00 \\
\hline Proaño-Pérez, et al. (40) & 2007 & Pichincha & Mejía & Bovine & $16 / 687$ & 2.33 \\
\hline Proaño-Pérez, et al. (40) & 2008 & Pichincha & Mejía & Bovine & $17 / 703$ & 2.24 \\
\hline
\end{tabular}

\section{Laboratory diagnosis}

Laboratory-based techniques are important for improving diagnosis of mycobacteria and identifying the species. In the slaughterhouse survey in the Mejía canton, all positive cultures obtained from tissue samples of tuberculous-like lesions were identified (40). Apart from M. bovis, NTM were also identified, i.e., $M$. gordonae, M. szulgai, M. celatum, and M. avium-intracellulare-scrofulaceum; however their clinical relevance was not further investigated. In addition, polymerase chain reaction (PCR) based on $16 \mathrm{~S}$ rRNA (ribosomal ribonucleic acid) confirmed the presence of $M$. bovis and NTM in lungs and lymph nodes (14).

DNA-fingerprinting analysis allowed identifying different $M$. bovis strains. All M. bovis isolates from the Mejía canton surveys displayed the same spoligotype (SB0980) (40). The homogeneity of the isolates found in this study could reflect a short timeframe of events. $M$. bovis spoligotypes have been reported to change in vitro in approximately 60 years (57), which could suggest that BTB was introduced into this dairy area together with new, European cattle breeds in the mid-Twentieth century.

\section{ZOONOTIC TB}

M. bovis infection in humans can occur through inhalation of infectious droplets from a live or slaughtered animal or by consumption of unpasteurized dairy or meat products from infected animals $(58,59)$. People working in animal husbandry, slaughterhouse workers, veterinarians, and people in close contact with possibly-infected animals are at a higher risk for M. bovis infection (60). In Argentina, a 2.4\% prevalence of zoonotic TB has been reported, with a high association with type of work performed (9). Lack of hygiene, existence of informal trade, absence of veterinary inspection, ignorance of the disease, and deficient use of gloves have been reported as risk factors among slaughterhouse workers (61).

In Ecuador, human cases of TB detected in public and private hospitals are reported to the Ministry of Public Health, which is responsible for the human TB control program and provides free treatment. In 2009, the Ministry of Public Health reported 3317 microscopy-positive new cases of pulmonary TB, 584 cases of extra-pulmonary $\mathrm{TB}$, and 613 deaths caused by the disease nationwide (62). According to the World Health Organization (WHO), Ecuador reported 4703 cases of TB in 2009 (63).

The national reference laboratory, "Leopoldo Izquieta Pérez Institute" (LIP), (Guayaquil, Ecuador) identified only two $M$. bovis isolates based on their growth and/or morphological characteristics (in 1998-2005): one from the lymph node of a girl 1 year of age, and the other from a pulmonary specimen of a boy 3 years of age (64). However, it is important to take into account that $M$. bovis requires special conditions to grow in vitro. The appropriate medium to facilitate growth of the bacilli (65) should contain sodium pyruvate, but no glycerol, e.g., Stonebrink medium. The latter medium is not routinely used in the LIP laboratory. Secondly, a number of human $M$. bovis infections might be misdiagnosed because the procedure required for differentiating between $M$. bovis and the other members of the M. tuberculosiscomplex is not routinely performed.

In 2007, a study was conducted on 157 farm and slaughterhouse workers from the Mejía canton to evaluate TB prevalence by tuberculin skin testing (TST). A positive reaction was seen in $29 \%$. In addition, the risk factors associated with disease transmission among this population were studied. A significant association was documented between TST positivity and masculine gender $(P=0.02$; odds ratio $[\mathrm{OR}]=2.5)$ and consumption of raw milk $(P<0.00)$ or cheese made by hand/homemade $(P=0.003)$ (66). These findings 
clearly show that cultural habits play a major role in risk behavior; consumption of raw milk is considered healthier and is widespread among this population group.

\section{ECONOMIC LOSSES FROM BTB}

The national economic losses due to BTB cannot be accurately calculated because standardized data is lacking, and the data that does exist is simply an estimate of BTB prevalence. However, the economic losses in the Mejía canton are estimated at approximately US\$ 460000 per year. This estimation is based on the true prevalence determined in 2008 by CITT (15) and official data on the cattle population for this canton: approximately 55000 head of cattle distributed among 2722 herds (12). Three important factors were considered in estimating economic losses caused by affected cattle: decreased milk production (13\%), weight loss $(36 \%)$, and decreased reproductive rate (12\%) (10). Nevertheless, the condemnation of carcasses was not taken into account for this calculation because the BTB-suspected cattle were not always entirely destroyed due to a lack of sanitary controls in some slaughterhouses.

\section{BTB CONTROL PROGRAM}

Today, the quality of dairy products is a high priority for the global dairy industry, as it is for Ecuador's. In Ecuador, the Ministry of Agriculture and Livestock's food safety department focuses on the quality of animal products. The private dairy sector pays more to dairy farmers who have earned a health certificate, awarded by the Ministry of Agriculture and Livestock, declaring their herd to be free of brucellosis and BTB. In theory, this status should be granted only after two consecutive negative results, meaning disease is not found among the herd, at two 6-month controls. In addition, the certification should be granted only by the Ministry of Agriculture and Livestock. However, this is not always the case in practice. Private laboratories offer tuberculin testing for cattle, but the tests are generally not administered by qualified veterinarians. Plus, the quality of PPD is not tested because there is no reference laboratory for animal diseases.

In general, BTB control programs are based on the early diagnosis and rapid elimination of positive CITT reactors on farms and at trade. Complementary strategies are recommended, i.e., epidemiological surveillance, proper veterinary supervision at slaughterhouses and cattle markets, and adequate control of cattle movement (67). In Spain, such a policy has been implemented since 1965, resulting in reduced BTB prevalence among cattle (68).

In Ecuador, there is no national BTB control program implemented yet. A national policy should be established with an obligatory CITT and culling of positive reactors. However, the implementation of such a national program has economic and logistic limitations. The total cost of a control program cannot be financed by the government alone; it should be shared with the private sector. Financial support should cover all related expenses, i.e., education and public awareness, incentives for farmers to improve the health status of their herds (through the price of the milk), regular CITT, compensation for culling, surveillance monitoring, and research.

\section{NEXT STEPS}

In conclusion, the data presented by this article confirm the presence of BTB in beef and dairy cattle in Ecuador, and justify the implementation of a national health policy to control the disease. A national control program is urgently needed to avoid the spread of BTB, and is an important step toward promoting international trade of animals and their products. Moreover, these measures would reduce the zoonotic impact of the disease among the population, especially in high-risk groups living in BTB-prevalent areas of the country. The situation in Ecuador may be similar to that of other countries in the Region of the Americas; thus the information present here could be used to help plan control and eradication programs elsewhere.

Acknowledgements. The authors gratefully acknowledge the financial support provided by the Commission Universitaire pour le Développement, University of Liege (Liege, Belgium), Project PIC (Programme interuniversitaire ciblé).

\section{SINOPSIS}

\section{Situación de la tuberculosis bovina en el Ecuador}

La tuberculosis bovina es una enfermedad contagiosa crónica que afecta a los animales domésticos, los animales salvajes y los seres humanos. Es producida por Mycobacterium bovis; causa grandes pérdidas económicas y plantea una grave limitación para el comercio ganadero internacional. Por otro lado, en los países en desarrollo donde no hay controles de la tuberculosis bovina, la infección por M. bovis representa un problema de salud pública. En la mayoría de los países en desarrollo, la prevalencia de tuberculosis en el ganado se desconoce porque la información no se comunica o no se consigue. En el Ecuador no hay un programa nacional de control de la tuberculosis bovina.

En este artículo se revisa la situación de la tuberculosis bovina en el Ecuador, sobre la base de un análisis de los datos exhaustivos obtenidos de encuestas sobre pruebas de tuberculina y de los estudios de vigilancia llevados a cabo en mataderos entre 1972 y 2008 en varias zonas geográficas del país. En el Ecuador varios factores, como el crecimiento de la industria láctea (impulsado por la alta demanda de leche y sus derivados), los intensos esfuerzos para aumentar la población bovina, la presencia de $\mathrm{M}$. bovis y la falta de con- 
troles de la tuberculosis bovina, han ocasionado un aumento de la prevalencia de esta $y$, en consecuencia, representan una motivación creciente para llevar a cabo un programa nacional de control de la tuberculosis bovina.
Palabras clave: Mycobacterium bovis; zoonosis; enfermedades de los bovinos; tuberculosis bovina; enfermedades transmisibles emergentes; Ecuador.

\section{REFERENCES}

1. Acha P, Szyfres B. Zoonoses and communicable diseases common to man and animals. In: Bacterioses and mycoses. 3rd ed. Washington D.C.: Pan American Health Organization; 2001. Pp. 283-299. (Scientific and Technical Publication 580).

2. Office International des Epizooties. Código sanitario para los animales terrestres. Vol 2. Available from: http:// www.oie.int/es/normas-interna cionales/codigo-terrestre/acceso-enlinea/ Accessed on 12 April 2011.

3. de Kantor IN, Ritacco V. An update on bovine tuberculosis programmes in Latin American and Caribbean countries. Vet Microbiol. 2006;112(2-4): 111-8.

4. Cosivi O, Grange JM, Daborn CJ Raviglione MC, Fujikura T, Cousins D, et al. Zoonotic tuberculosis due to Mycobacterium bovis in developing countries. Emerg Infect Dis. 1998;4(1): 59-70.

5. Gil A, Samartino L. Zoonosis en los sistemas de producción animal de las áreas urbanas y periurbanas de América Latina. Rome: FAO; 2001. Pp. 16-22. (Livestock Policy Discussion Paper No. 2).

6. Michel AL, Müller B, van Helden PD. Mycobacterium bovis at animal-human interface: A problem or not? Vet Microbiol. 2010;140(3-4):371-81.

7. Brown C. Emerging diseases of animals: an overview. In: Emerging diseases of animals. Brown C, Bolin C, eds. Washington DC: ASM Press; 2000. Pp. 1-12.

8. Abalos P, Retamal P. Tuberculosis: ¿una zoonosis re-emergente? Rev Sci Tech Off int Epiz. 2004;23(2):583-94.

9. Latini O, Canal AM, Ferrara ME, Sequeira MD, Sequeira G, Bagnaroli R, et al. Confiabilidad en la determinación de prevalencia de infección por $M y$ cobacterium bovis en ganado bovino por decomisos en frigoríficos. Arch Med Vet. 1997;29(2):197-204.

10. Suazo FM, Escalera AM, Torres RM. A review of $M$. bovis BCG protection against TB in cattle and other animals species. Prev Vet Med. 2003;58(1-2): 1-13.

11. Humblet MF, Boschiroli ML, Saeger man C. Classification of worldwide bovine tuberculosis risk factors in cattle: a stratified approach. Vet Res. 2009; 40(5):50.

12. Servicio de Informática y Censo Agropecuario. Tercer Censo Nacional Agropecuario, 2000. Available from: http:/ / www.sica.gov.ec/censo/docs/ nacionales/tabla6.htm Accessed on 2 May 2008.
13. Monaghan ML, Doherty ML, Collins JD, Kazda JF, Quinn PJ. The tuberculin test. Vet Microbiol. 1994;40(1-2):111-24.

14. Proaño-Perez F, Rigouts L, Brandt J, Dorny P, Ron J, Chavez M, et al. Preliminary observations on Mycobacterium spp in dairy cattle in Ecuador. Am J Trop Med Hyg. 2006;75(2):318-23.

15. Proaño-Pérez F, Benítez-Ortiz W, CeliErazo M, Ron-Garrido L, BenítezCapistros R, Portaels F, et al. Comparative intradermal tuberculin test in dairy cattle in the north of Ecuador and risk factors associated with bovine tuberculosis. Am J Trop Med Hyg. 2009;81(6): 1103-9.

16. Acosta $C$, Parreño B. Incidencia de tuberculosis bovina en veinte haciendas del cantón Píllaro. [Thesis]. Quito: Facultad de Medicina Veterinaria, Universidad Central del Ecuador; 1977.

17. Alemán R, Cajilema C, Jaramillo F. Diagnóstico de Tuberculosis Bovina mediante la prueba intradérmica única en hatos lecheros de la provincia de Tungurahua. [Thesis]. Quito: Facultad de Medicina Veterinaria, Universidad Central del Ecuador; 2003.

18. Andino-Ashqui O. Diagnóstico de Tuberculosis bovina mediante la prueba intradérmica única en hatos lecheros de la Sierra Ecuatoriana. [Thesis]. Quito: Facultad de Medicina Veterinaria, Universidad Central del Ecuador; 2001.

19. Bedón T, Verdesoto S. Diagnóstico de tuberculosis bovina mediante la prueba intradérmica única en hatos lecheros de la provincia de Imbabura. [Thesis]. Quito: Facultad de Medicina Veterinaria, Universidad Central del Ecuador; 2003.

20. Burbano R, León J. Diagnóstico de la Tuberculosis bovina mediante la prueba intradérmica única en hatos lecheros de los cantones Espejo, Montufar, Tulcán y Huaca en la provincia del Carchi. [Thesis]. Quito: Facultad de Medicina Veterinaria, Universidad Central del Ecuador; 2002.

21. Salazar JC, Cevallos C. Diagnóstico de la Tuberculosis bovina mediante la prueba intradérmica única en hatos lecheros del cantón Cayambe en la provincia del Pichincha. [Thesis]. Quito: Facultad de Medicina Veterinaria, Universidad Central del Ecuador; 2002.

22. Cano G, Chulde P. Diagnóstico de la Tuberculosis bovina mediante la prueba intradérmica única en hatos lecheros del cantón Mejía en la provincia de Pichincha. [Thesis]. Quito: Facultad de Medicina Veterinaria, Universidad Central del Ecuador; 2002.
23. Goodchild AV, Clifton-Hadley RS. Cattle-to-cattle transmission of $\mathrm{Myco}$ bacterium bovis. Tuberculosis (Edinb). 2001;81(1-2):23-41.

24. Ameni G, Aseffa A, Engers H, Young D, Gordon, S, Hewinson G, et al. High prevalence and increased severity of pathology of bovine tuberculosis in Holsteins compared to zebu breeds under field cattle husbandry in Central Ethiopia. Clin Vaccine Immunol. 2007; 14(10):1356-61.

25. Phillips CJ, Foster CR, Morris PA Teverson R. The transmission of $\mathrm{Myco}^{-}$ bacterium bovis infection to cattle. Res Vet Sci. 2003;74(1):1-15.

26. Cañizares R. Diagnóstico de la tuberculosis bovina utilizando el derivado protéico purificado (PPD) en algunos hatos del cantón Guayaquil. [Thesis]. Guayaquil: Facultad de Medicina Veterinaria, Universidad Agraria del Ecuador; 1977.

27. Maretti A. Prevalencia de tuberculosis en el ganado bovino en la isla San Cristóbal, Provincia de Galápagos. [Thesis]. Machala: Facultad de Agronomía y Veterinaria, Universidad Técnica de Machala; 1981.

28. Lojan F. Prevalencia de tuberculosis en hembras bovinas adultas del Cantón Santa Rosa, provincia de El Oro. [Thesis]. Machala: Facultad de Agronomía y Veterinaria, Universidad Técnica de Machala; 1982.

29. Aguirre E. Prevalencia de tuberculosis en el ganado bovino en cantón Pasaje, provincia de El Oro. [Thesis]. Machala: Facultad de Agronomía y Veterinaria, Universidad Técnica de Machala; 1984.

30. Torres L, Burbano D, Rivadeneira E. Diagnóstico de tuberculosis bovina mediante la prueba intradérmica única de tuberculina PPD en la Hacienda San Antonio. [Thesis]. Quito: Facultad de Medicina Veterinaria, Universidad Central del Ecuador; 1996.

31. Gutiérrez M. Determinación de tuberculosis en hatos ganaderos del cantón el Triunfo, provincia del Guayas. [Thesis]. Guayaquil: Facultad de Medicina Veterinaria, Universidad Agraria del Ecuador; 1997.

32. Muñoz M. Determinación de tuberculosis bovina en la parroquia Quinsaloma del cantón Ventanas. [Thesis]. Guayaquil: Facultad de Medicina Veterinaria, Universidad Agraria del Ecuador; 1998.

33. Villamar J. Prevalencia de tuberculosis bovina en hatos del cantón Paján, provincia de Manabí. [Thesis]. 
Guayaquil: Facultad de Medicina Veterinaria, Universidad Agraria del Ecuador; 2000.

34. Moncada F. Determinación de la prevalencia de tuberculosis bovina en hatos lecheros del cantón Naranjal. [Thesis]. Guayaquil: Facultad de Medicina Veterinaria, Universidad Agraria del Ecuador; 2003.

35. Avellán E. Determinación de tuberculosis bovina en hatos lecheros del cantón Bucay, provincia del Guayas. [Thesis]. Guayaquil: Facultad de Medicina Veterinaria, Universidad Agraria del Ecuador; 2003.

36. Arévalo C, Zamora D. Diagnóstico de la Tuberculosis bovina mediante la prueba intradérmica única en hatos lecheros en Santo Domingo de los Colorados. [Thesis]. Quito: Facultad de Medicina Veterinaria, Universidad Central del Ecuador; 2004

37. Biet F, Boschiroli ML, Thorel MF, Guilloteau L. Zoonotic aspects of $M y$ cobacterium bovis and Mycobacterium avium-intracellulare complex (MAC). Vet Res. 2005;36(3):411-36.

38. Neill SD, Pollock JM, Bryson DB, Hanna J. Pathogenesis of Mycobacterium bovis infection in cattle. Vet Microbiol. 1994; 40 (1-2):41-52.

39. Whipple DL, Bolin CA, Miller JM. Distribution of lesions in cattle infected with Mycobacterium bovis. J Vet Diagn Invest. 1996;8(3):351-4.

40. Proaño-Pérez F, Benítez-Ortiz W, Desmecht D, Coral M, Ortiz J, Ron L, et al. Post-mortem examination and laboratory-based analysis for the diagnosis of bovine tuberculosis among dairy cattle in Ecuador. Prev Vet Med. 2011;101 (1-2):65-72.

41. Villacís E. Investigación de tuberculosis porcina por estudio anatomopatológico e histológico en porcinos sacrificados en el matadero municipal de Guayaquil. [Thesis]. Guayaquil: Facultad de Agronomía y Veterinaria, Universidad de Guayaquil; 1972.

42. Mata M. Determinación del índice de bovinos tuberculosos que se sacrifican en el matadero municipal de la cuidad de Guayaquil. [Thesis]. Guayaquil: Facultad de Agronomía y Veterinaria, Universidad de Guayaquil; 1973.

43. Cruz N. Tuberculosis en porcinos sacrificados en el matadero municipal de la cuidad de Machala. [Thesis]. Machala: Facultad de Agronomía y Veterinaria, Universidad Técnica de Machala; 1985.

44. Haz J. Diagnóstico post-mortem de tuberculosis en porcinos despostados en el camal municipal de Vinces. [Thesis]. Guayaquil: Facultad de Agronomía y Veterinaria, Universidad de Guayaquil; 1987.

45. Cueto N, Suárez M. Porcentaje de lesiones tuberculosas encontradas en animales de abasto a nivel de matadero y su verificación con diagnostico bacteriológico. [Thesis]. Guayaquil: Facultad de Medicina Veterinaria, Universidad Agraria del Ecuador; 1993.

46. Andrade Y. Prevalencia de tuberculosis en caprinos despostados en el camal municipal de Guayaquil. [Thesis]. Guayaquil: Facultad de Medicina Veterinaria, Universidad Agraria del Ecuador; 2000.

47. Coloma L. Determinación de tuberculosis en bovinos sacrificados en el matadero municipal de Santo Domingo de los Colorados. [Thesis]. Guayaquil: Facultad de Medicina Veterinaria, Universidad Agraria del Ecuador; 2000.

48. Villón W. Prevalencia de tuberculosis bovina a nivel del matadero municipal de Guayaquil. [Thesis]. Guayaquil: Facultad de Medicina Veterinaria, Universidad Agraria del Ecuador; 2002.

49. Torres D. Determinación de la prevalencia de tuberculosis en bovinos sacrificados en el camal municipal del cantón Pasaje. [Thesis]. Machala: Facultad de Agronomía y Veterinaria, Universidad Técnica de Machala; 2002.

50. Jaramillo B. Presencia de tuberculosis bovina en animales sacrificados en el camal municipal de Santa Rosa. [Thesis]. Machala: Facultad de Agronomía y Veterinaria, Universidad Técnica de Machala; 2002.

51. Jáuregui D. Determinación de tuberculosis en bovinos sacrificados en el camal de Colimes, por medio de lesiones anatomopatológicas. [Thesis]. Guayaquil: Facultad de Medicina Veterinaria, Universidad Agraria del Ecuador; 2003.

52. Mera M. Diagnóstico post-mortem de tuberculosis en bovinos faenados en el camal municipal del cantón Quinindé, Provincia de Esmeraldas. [Thesis]. Guayaquil: Facultad de Medicina Veterinaria, Universidad Agraria del Ecuador; 2003.

53. Nassar AF, Miyashiro S, Oliveira CG, Pacheco WA, Ogata RA. Isolation and identification of bovine tuberculosis in a Brazilian herd (São Paulo). Mem Inst Oswaldo Cruz. 2007;102(5):639-42.

54. Pires de Araújo C, Leite CQ, Andrade de Prince KA, Jorge K, Osório AL. Mycobacterium bovis identification by a molecular method from post-mortem inspected cattle obtained in abattoirs of Mato Grosso do Sul, Brazil. Mem Inst Oswaldo Cruz. 2005;100(7):749-52.

55. Milian-Suazo F, Salman MD, Ramirez C, Payeur JB, Rhyan JC, Santillan M. Identification of tuberculosis in cattle slaughtered in Mexico. Am J Vet Res. 2000;61(1):86-9.

56. Brown WH, Hernández de Anda J. Tuberculosis in adult beef cattle of Mexican origin shipped direct-to-slaughter into Texas. J Am Vet Med Assoc. 1998;212(4):557-9.
57. Fang Z, Morrison N, Watt B, Doig C, Forbes KJ. IS6110 transposition and evolutionary scenario of the direct repeat locus in a group of closely related $M y$ cobacterium tuberculosis strains. J Bacteriol. 1998;180(8):2102-9.

58. Grange JM. Mycobacterium bovis infection in human beings. Tuberculosis (Edinb). 2001;81(1-2):71-7.

59. LoBue P. Public health significance of Mycobacterium bovis. In: Thoen C, Steele J, Gilsdorf M, eds. Mycobacterium bovis infection in animals and humans. 2nd ed. Iowa: Blackwell Publishing Press; 2006. Pp. 6-12.

60. Cousins DV, Dawson DJ. Tuberculosis due to Mycobacterium bovis in the Australian population: cases recorded during 1970-1994. Int J Tuberc Lung Dis. 1999:3(8):715-21.

61. Wilkins M, Bartlett P, Frawley B, O'Brien D, Miller C, Boulton M. Mycobacterium bovis (bovine $\mathrm{TB}$ ) exposure as a recreational risk for hunters: results of a Michigan Hunter Survey, 2001. Int J Tuberc Lung Dis. 2003;7(10):1001-9.

62. Ministerio de Salud Pública del Ecuador. Informe de gestión del programa de Control de tuberculosis en Ecuador 2005-2009. Quito: MSP; 2010.

63. World Health Organization. Global tuberculosis control: surveillance, planning, financing. Geneva: WHO; 2010. Available from: http://www.who.int/ tb/publications/global_report/2010/ en/index.html Accessed on 7 April 2011.

64. de Kantor IN, Ambroggi M, Poggi S, Morcillo N, Da Silva Telles MA, Osório Ribeiro M, et al. Human Mycobacterium bovis infection in ten Latin American countries. Tuberculosis (Edinb). 2008; 88(4):35-65.

65. Parks LC. Microbiological Media. Second edition. New York: CRC Press; 1997. Pp. 774-6.

66. Benítez-Capistros R. Prevalencia de Mycobacterium spp. en poblaciones en riesgo del cantón Mejía, Pichincha Ecuador. [Thesis]. Quito: Facultad de Biología, Pontifica Universidad Católica del Ecuador; 2007.

67. Collins JD. Tuberculosis in cattle: strategic planning for the future. Vet Microbiol. 2006;112(2-4):369-81.

68. Aranaz A, Liebana E, Mateos A, Dominguez L, Vidal D, Domingo $M$, et al. Spacer oligonucleotide typing of Mycobacterium bovis strains from cattle and other animals: a tool for studying epidemiology of tuberculosis. J Clin Microbiol. 1996;34(11):2734-40.

Manuscript received on 24 January 2011. Revised version accepted for publication on 17 April 2011. 